Jurnal Indonesia Sosial Teknologi: p-ISSN: 2723 - 6609

e-ISSN : 2745-5254

Vol. 2, No. 2 Februari 2021

\title{
PENGARUH KOMPETENSI TERHADAP PRODUKTIVITAS KERJA DENGAN KEPUASAN KERJA SEBAGAI MODERATOR DI BANDAR UDARA INTERNASIONAL I GUSTI NGURAH RAI BALI
}

\section{Satria Panji Wijayanto, Derriawan dan Fahruddin Salim}

Sekolah Pascasarjana Universitas Pancasila, Jakarta, Indonesia.

Email: satriapanji.3110@gmail.com, deri_awan@yahoo.co.id, fahruddinsalim@gmail.com

\begin{abstract}
This study aims to analyze the influence of the competence of employees of PT Angkasa Pura I (Persero), especially I Gusti Ngurah Rai Bali International Airport in increasing work productivity through aspects of appreciation and promotion in the workplace. This study also uses job satisfaction as a moderating variable to see its role in strengthening or weakening the relationship to work productivity. The research method used is a quantitative design with the method of taking a questionnaire to 240 respondents from the employees of I Gusti Ngurah Rai International Airport, Bali. The analysis process used is descriptive and verification with the SEM Partial Least Square (PLS) method. The results of the study using the SmartPLS 3.0 aid show that there are 4 out of 9 hypotheses that do not have a significant effect, namely. Meanwhile, there is no significant effect of rewards and promotions on work productivity, competence and promotion on work productivity which is moderated by job satisfaction. Competence has the greatest influence on work productivity compared to other variables.
\end{abstract}

Keywords: competence; appreciation; promotion; job satisfaction; work productivity.

\begin{abstract}
Abstrak
Penelitian ini bertujuan untuk menganalisis pengaruh kompetensi karyawan PT Angkasa Pura I (Persero), khususnya Bandar Udara Internasional I Gusti Ngurah Rai Bali dalam menigkatkan produktivitas kerja yang melalui aspek penghargaan dan promosi di tempat kerja. Penelitian ini juga menggunakan kepuasan kerja sebagai variabel moderator untuk melihat perannya dalam memperkuat atau memperlemah hubungan terhadap produktivitas kerja. Metode penelitian yang digunakan yaitu desain kuantitatif dengan metode pengambilan kuesioner kepada 240 responden yang berasal dari karyawan Bandar Udara Internasional I Gusti Ngurah Rai Bali. Proses analisis yang digunakan yaitu berupa deskriptif dan verifikatif dengan metode SEM Partial Least Square (PLS). Hasil penelitian dengan menggunakan bantuan SmartPLS 3.0 menunjukkan bahwa terdapat 4 dari 9 hipotesis yang tidak memiliki pengaruh signifikan yaitu. Sedangkan tidak terdapat pengaruh yang signifikan dari penghargaan dan promosi terhadap produktivitas kerja, kompetensi dan promosi terhadap produktivitas kerja yang dimoderasi oleh kepuasan kerja. Kompetensi memiliki pengaruh paling besar terhadap produktivas kerja dibandingkan dengan variabel lainnya.
\end{abstract}


Kata kunci: kompetensi; penghargaan; promosi; kepuasan kerja; produktivitas kerja.

\section{Pendahuluan}

Perusahaan merupakan setiap bentuk usaha yang bersifat tetap, terus menerus dan yang didirikan, bekerja serta berkedudukan dalam wilayah negara Republik Indonesia. Tujuan perusahaan adalah memperoleh keuntungan atau laba (Pemerintah Republik Indonesia, 1982). Berdasarkan hal tersebut, tujuan utama dari suatu perusahaan yaitu untuk menghasilkan laba setinggi-tingginya demi keberlangsungan perusahaan dalam jangka panjang.

PT. Angkasa Pura I (Persero) sebagai salah satu Badan Usaha Milik Negara (BUMN) yang bergerak di bidang jasa kebandarudaraan dituntut untuk selalu menghasilkan laba sesuai dengan statusnya sebagai Perusahaan Perseroan (Persero) dalam memberikan keuntungan kepada kas negara sebanyak-banyaknya.

Kegiatan operasional di Bandara tidak dapat terlepaskan dari target Keselamatan, Keamanan, dan Pelayanan serta Pemenuhan Regulasi $(3 \mathrm{~S}+1 \mathrm{C})$ terhadap proses bisnis yang ada di Bandara yang meliputi Pelayanan Jasa Penumpang Pesawat Udara (PJP2U), Pelayanan Jasa Pendaratan, Penempatan dan Penyimpanan Pesawat Udara (PJP4U) dan Pelayanan Jasa Kargo dan Pos Pesawat Udara (PJKP2U).

Salah satu bandar udara yang di kelola oleh PT Angkasa Pura I (Persero) yaitu Bandar Udara Internasional I Gusti Ngurah Rai - Bali. Bandar Udara Internasional I Gusti Ngurah Rai - Bali merupakan Kantor Cabang Bandar Udara Kelas Utama dan terbesar yang dimiliki oleh PT Angkasa Pura I (Persero) dimana lebih dari 50\% total pendapatan yang didapatkan oleh PT Angkasa Pura I (Persero) berasal dari Bandar Udara I Gusti Ngurah Rai - Bali. Oleh karena itu, pendapatan dari perusahaan sangat tergantung dari pendapatan dan kondisi yang ada di Bandar Udara I Gusti Ngurah Rai - Bali (Laporan Tahunan PT Angkasa Pura I Tahun 2016-2018).

Menurut (PT Angkasa Pura I (Persero), 2019) terdapat penurunan penumpang sekitar 19\% yang berdampak pada laba yang diperoleh oleh PT. Angkasa Pura I (Persero) hingga Semester I 2019 yaitu hanya 870 M. Hal ini masih jauh dari 50\% laba yang diperoleh pada Tahun 2018 yaitu lebih dari 2 triliun.

Berdasarkan dari kondisi di atas, PT. Angkasa Pura I (Persero) perlu menentukan strategi terbaik untuk tetap dapat meningkatkan produktivitas dan mencapai target perusahaan yang telah ditetapkan. Dalam pelaksanaan kegiatan operasional di Bandara tentu terdapat banyak tantangan di dalam mencapai suatu kegiatan operasional yang unggul. Faktor kepuasan kerja karyawan menjadi salah satu faktor di dalam kelancaran kegiatan operasional di Bandara dalam menjamin peningkatan kualitas dan memberikan layanan prima untuk memuaskan pelanggan (PT Angkasa Pura I (Persero), 2019)

Berkaitan dengan operasional bandar udara di PT. Angkasa Pura I (Persero), diperlukan sumber daya manusia yang memiliki keterampilan khusus dengan harapan untuk memperoleh hasil yang terbaik. 
Oleh sebab itu, perlu dilakukan suatu pengukuran produktivitas di lapangan yang bertujuan untuk mengetahui tolak ukur produktivitas yang telah dicapai oleh perusahaan dan merupakan dasar dari perencanaan bagi peningkatan efektivitas dan efisiensi bandara udara di masa yang akan datang.

Selain itu, pemberian penghargaan dan promosi kerja juga erat kaitannya dengan peningkatan produktivitas kerja karyawan. (Lau, 2018) penghargaan dan promosi merupakan faktor paling penting di dalam meningkatkan produktivitas kerja karyawan.

Berdasarkan (PT Angkasa Pura I (Persero), 2018) Penghargaan, Sanksi dan Keamanan Kerja (Gap -0,46) dan Rekrutmen dan Pola Karir (Gap -0,47) merupakan 3 besar faktor atribut yang termasuk ke dalam kuadran prioritas untuk perbaikan pada Bandar Udara I Gusti Ngurah Rai - Bali.

Menurut (PT Angkasa Pura I (Persero), 2019), atribut di dalam kuadran prioritas untuk perbaikan, khusunya pada Bandara I Gusti Ngurah Rai Strategic Bussiness Unit Commercial memuat tentang pemberian penghargaan yang dilakukan oleh perusahaan (keuangan maupun non keuangan) yang memadai untuk kinerja baik atau melebihi target, dimana poin ini memiliki skor ESI terendah yaitu 3,88.

Berdasarkan beberapa permasalahan yang telah dijelaskan dijelaskan di atas, penulis ingin meneliti lebih dalam mengenai pengaruh kompetensi terhadap produktivitas kerja melalui penghargaan dan promosi dengan kepuasan kerja sebagai moderator di PT. Angkasa Pura I (Persero) - Kantor Cabang Bandar Udara Internasional I Gusti Ngurah Rai - Bali.

\section{Metode Penelitian}

Dalam penelitian ini menggunakan pendekatan kuantitatif. Penelitian kuantitatif merupakan penelitian yang berlandaskan pada filsafat positivisme, digunakan untuk meneliti populasi dan sampel tertentu, teknik pengambilan sampel pada umumnya dilakukan secara random, pengumpulan data menggunakan instrument penelitian, analisis data bersifat statistik yang bertujuan untuk menguji hipotesis yang telah ditetapkan (Sugiyono, 2016). Teknik pengumpulan data dilakukan dengan metode survey dan data yang digunakan adalah data primer. Penelitian dilakukan di P.T. Angkasa Pura I (Persero) dengan lokasi kerja Kantor Cabang Bandar Udara Internasional I Gusti Ngurah Rai - Bali.

Adapun populasi dalam penelitian ini adalah seluruh karyawan organik di PT Angkasa Pura I (Persero) dengan lokasi kerja Kantor Cabang Bandar Udara Internasional I Gusti Ngurah Rai - Bali, dengan jumlah sampel sebanyak 240 responden dari total 575 karyawan. Penelitian ini menggunakan instrumen berupa kuesioner dengan skala likert.

Metode yang digunakan dalam penelitian ini yaitu metode analisis statistik deskriptif, yaitu untuk menganalisis data dengan cara mendeskripsikan atau menggambarkan data yang telah terkumpul sebagaimana adanya tanpa bermaksud membuat kesimpulan yang berlaku untuk umum atau generalisasi (Sugiyono, 2016). Sedangkan metode statistik yang digunakan adalah Structural Equation Modelling (SEM), yaitu suatu teknik statistik yang mampu menganalisis pola hubungan antara 
kontruk laten dan indikatornya, kontruk laten yang satu dengan yang lainnya. Software yang digunakan dalam mengolah data adalah Smart Partial Least Square (PLS).

Penelitian ini terdiri dari 5 variabel yaitu kompetensi sebagai variabel independen; produktivitas kerja sebagai variabel dependen; penghargaan dan promosi sebagai variabel mediasi; serta kepuasan kerja sebagai variabel moderator.

\section{Hasil dan Pembahasan}

a. Evaluasi Model Pengukuran (Outer Model)

Dalam PLS untuk mengukur reliabilitas suatu konstruk dengan indikator refleksif dapat dilakukan dengan uji composite reliability dengan ketentuan apabila konstruk memiliki nilai Composite Reliability yang lebih besar dari 0.70, nilai Cronbanchs Alpha yang lebih besar dari 0.70, dan nilai Average Variance Extracted (AVE) yang lebih besar dari 0.50, dapat disimpulkan bahwa variabel manifes memiliki akurasi, konsistensi dan ketepatan instrumen yang baik dalam mengukur konstruk.

Hasil pengujian menggunakan software Smart PLS 3.0, disajikan pada tabel berikut:

Tabel 1.

Hasil Output Latent Variable Coefficients

\begin{tabular}{ccccc}
\hline Variabel Laten & AVE & $\begin{array}{c}\text { Cronbach's } \\
\text { Alpha }\end{array}$ & $\begin{array}{c}\text { Composite } \\
\text { Reliability }\end{array}$ & Keterangan \\
\hline $\begin{array}{c}\text { Kepuasan } \\
\text { Kerja (W) }\end{array}$ & 0.507 & 0.893 & 0.910 & Reliabel \\
\hline $\begin{array}{c}\text { Kompetensi } \\
(\mathrm{X})\end{array}$ & 0.521 & 0.874 & 0.898 & Reliabel \\
\hline $\begin{array}{c}\text { Moderating } \\
\text { Effect WX }\end{array}$ & 1.000 & 1.000 & 1.000 & Reliabel \\
\hline $\begin{array}{c}\text { Moderating } \\
\text { Effect WZ1 }\end{array}$ & 1.000 & 1.000 & 1.000 & Reliabel \\
\hline $\begin{array}{c}\text { Moderating } \\
\text { Effect WZ2 }\end{array}$ & 1.000 & 1.000 & 1.000 & Reliabel \\
\hline $\begin{array}{c}\text { Penghargaan } \\
(\mathrm{Z1})\end{array}$ & 0.538 & 0.785 & 0.853 & Reliabel \\
\hline $\begin{array}{c}\text { Produktivitas } \\
\text { Kerja (Y) }\end{array}$ & 0.528 & 0.705 & 0.817 & Reliabel \\
\hline Promosi (Z2) & 0.519 & 0.815 & 0.855 & Reliabel \\
\hline
\end{tabular}

Sumber: Data primer (diolah penulis)

\section{b. Evaluasi Model Struktural (Inner Model)}

Inner Model merupakan uji pada model struktural yang dilakukan untuk menguji hubungan antara konstruk laten. Dalam penelitian ini pengujian inner model dilakukan dengan memperlihatkan nilai $\mathrm{R}^{2}$ pada variabel laten endogen. Berdasarkan 
hasil pengujian menggunakan software SmartPLS 3.0, diperoleh hasil sebagai berikut:

Tabel 2.

Nilai Koefisien Determinasi (Uji $\mathbf{R}^{\mathbf{2}}$ )

\begin{tabular}{ccc}
\hline & $\mathbf{R}^{2}$ & $\mathbf{R}^{2}$ Adjusted \\
\hline Penghargaan (Z1) & 0.248 & 0.245 \\
\hline $\begin{array}{c}\text { Produktivitas Kerja } \\
(Y)\end{array}$ & 0.559 & 0.546 \\
\hline Promosi (Z2) & 0.310 & 0.308 \\
\hline
\end{tabular}

Sumber : Data primer (diolah penulis)

Berikut Gambar 1 yang merupakan hasil analisis model SEM di dalam penelitian ini dalam bentuk Path Diagram.

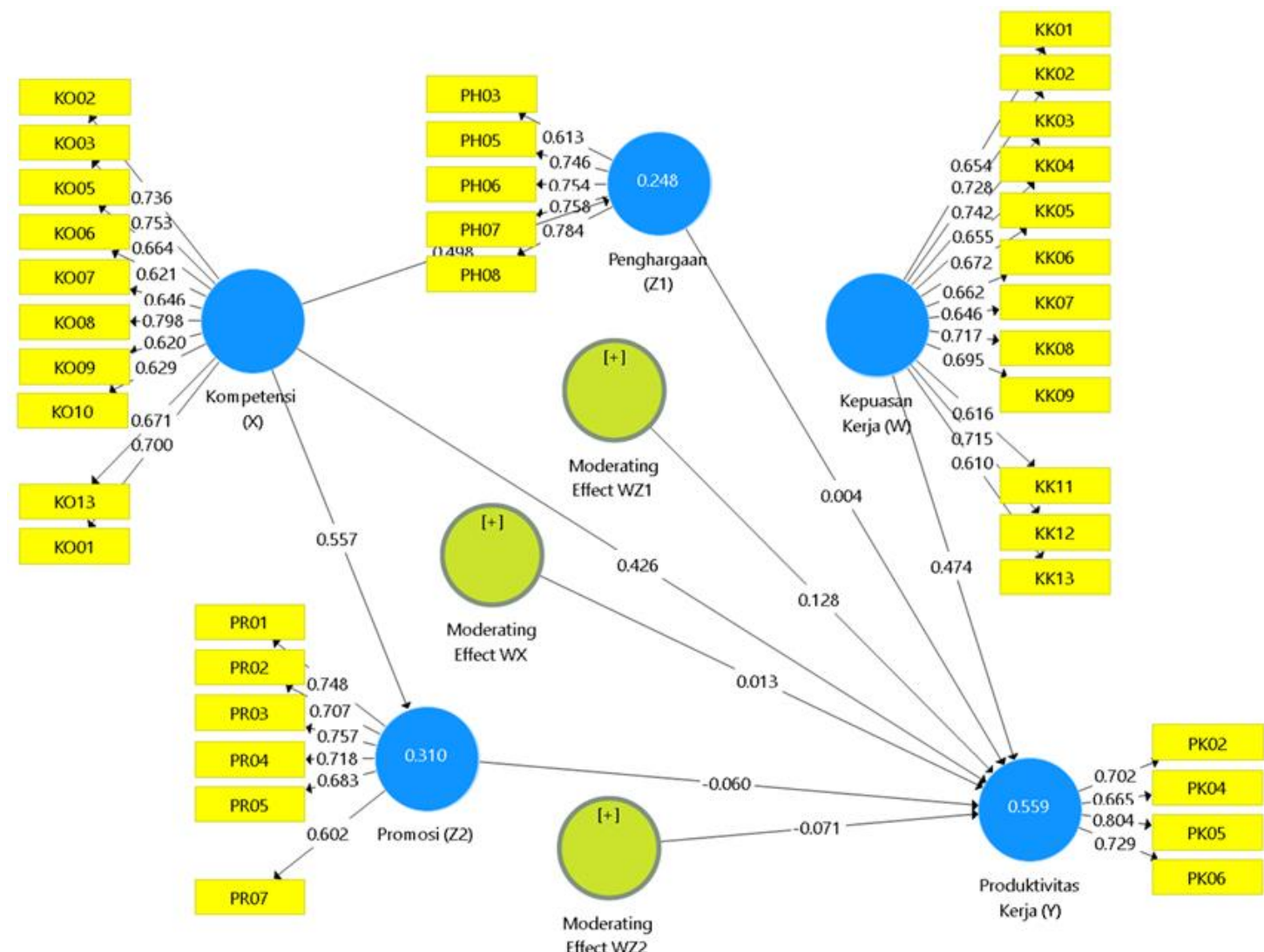

Gambar 1.

Hasil Analisis Model SEM Lengkap

\section{c. Uji Hipotesis}


Hipotesis dalam penelitian ini akan diuji dengan menggunakan nilai koefisien path dan $t$-values yang disajikan sebagai berikut :

Tabel 3.

Path Coefficient and T-Values

\begin{tabular}{lccc}
\hline \multicolumn{1}{c}{ Hubungan Konstruk } & $\begin{array}{c}\text { Path } \\
\text { Coefficient }\end{array}$ & $\begin{array}{c}T \\
\text { Statistics }\end{array}$ & Keterangan \\
\hline $\begin{array}{l}\text { Kepuasan Kerja (W) -> } \\
\text { Produktivitas Kerja (Y) }\end{array}$ & 0.474 & 6.391 & Signifikan \\
\hline $\begin{array}{l}\text { Kompetensi (X) -> } \\
\text { Penghargaan (Z1) }\end{array}$ & 0.498 & 7.975 & Signifikan \\
\hline $\begin{array}{l}\text { Kompetensi (X) -> } \\
\text { Produktivitas Kerja (Y) }\end{array}$ & 0.426 & 6.190 & Signifikan \\
\hline $\begin{array}{l}\text { Kompetensi (X) -> } \\
\text { Promosi (Z2) }\end{array}$ & 0.557 & 11.534 & Signifikan \\
\hline $\begin{array}{l}\text { Moderating Effect WX -> } \\
\text { Produktivitas Kerja (Y) }\end{array}$ & 0.013 & 0.187 & $\begin{array}{c}\text { Tidak } \\
\text { Signifikan }\end{array}$ \\
\hline $\begin{array}{l}\text { Moderating Effect WZ1 -> } \\
\text { Produktivitas Kerja (Y) }\end{array}$ & 0.128 & 2.247 & Signifikan \\
\hline $\begin{array}{l}\text { Moderating Effect WZ2 -> } \\
\text { Produktivitas Kerja (Y) }\end{array}$ & -0.071 & 1.212 & $\begin{array}{c}\text { Tidak } \\
\text { Signifikan }\end{array}$ \\
\hline $\begin{array}{l}\text { Penghargaan (Z1) -> } \\
\text { Produktivitas Kerja (Y) }\end{array}$ & 0.004 & 0.049 & $\begin{array}{c}\text { Tidak } \\
\text { Signifikan }\end{array}$ \\
\hline $\begin{array}{l}\text { Promosi (Z2) -> } \\
\text { Produktivitas Kerja (Y) }\end{array}$ & -0.060 & 0.773 & $\begin{array}{c}\text { Tidak } \\
\text { Signifikan }\end{array}$ \\
\hline Sumber: Data primer (diolah pentik) & & &
\end{tabular}

Sumber: Data primer (diolah penulis)

\section{Pembahasan}

1. Pengaruh Kompetensi terhadap Penghargaan di Bandar Udara Internasional I Gusti Ngurah Rai - Bali

Berdasarkan parameter statistik menunjukkan bahwa $t_{\text {hitung }}$ sebesar 7.975 lebih besar daripada $t_{\text {tabel }}$ sebesar 1.96 pada tingkat signifikansi 5\%. Artinya bahwa Kompetensi berpengaruh signifikan terhadap Penghargaan.

Kompetensi karyawan sangat dibutuhkan sebagai salah satu panduan di dalam pemberian penghargaan yang ada di perusahaan. Telah diketahui pula bahwa kompetensi karyawan dapat dilihat dari kompetensi dasar dan pembeda yang dimiliki oleh karyawan tersebut. Sedangkan kemampuan mengelola tugas, adapatasi dengan lingkungan dan kemampuan komunikasi dapat pula meningkatkan kompetensi karyawan.

Hasil penelitian membuktikan bahwa kompetensi berpengaruh signifikan terhadap penghargaan. Hal ini berarti semakin baik kompetensi karyawan, akan 
berdampak pada semakin meningkatnya penghargaan yang akan di dapat oleh karyawan tersebut. Selain itu, Hasil penelitian ini mendukung temuan sebelumnya oleh (Haskas, 2013) yang membuktikan bahwa kompetensi yang dimiliki oleh karyawan akan mendorong perusahaan untuk memberikan penghargaan.

2. Pengaruh Kompetensi terhadap Promosi di Bandar Udara Internasional I Gusti Ngurah Rai - Bali

Berdasarkan parameter statistik menunjukkan bahwa thitung sebesar 11.534 lebih besar daripada $t_{\text {tabel }}$ sebesar 1.96 pada tingkat signifikansi 5\%. Artinya bahwa kompetensi berpengaruh signifikan terhadap promosi.

Kompetensi karyawan merupakan salah satu faktor penentu di dalam promosi karyawan di perusahaan. Perusahaan membutuhkan karyawan dengan kompetensi yang tinggi untuk mengisi posisi strategis di perusahaan demi bersaing dengan kompetitor lainnya.

Hasil penelitian membuktikan bahwa kompetensi berpengaruh signifikan terhadap penghargaan. Hal ini berarti semakin baik kompetensi karyawan, akan berdampak pada semakin meningkatnya kesempatan promosi yang akan di dapat oleh karyawan tersebut di perusahaan. Hasil penelitian ini mendukung temuan sebelumnya oleh (Earlyanti, 2019) yang membuktikan bahwa kompetensi yang dimiliki oleh karyawan akan mendorong promosi karyawan di perusahaan.

3. Pengaruh Penghargaan terhadap Produktivitas Kerja di Bandar Udara Internasional I Gusti Ngurah Rai - Bali

Berdasarkan parameter statistik menunjukkan bahwa thitung sebesar 0.049 lebih kecil daripada $t_{\text {tabel }}$ sebesar 1,96 pada tingkat signifikansi 5\%. Artinya bahwa Penghargaan tidak berpengaruh signifikan terhadap produktivitas kerja.

Penghargaan yang diberikan oleh perusahaan sejatinya dapat memacu karyawan untuk dapat bekerja lebih baik lagi dan semakin produktif. Penghargaan dapat menjadi nilai tambah bagi karyawan sehingga karyawan akan merasa bangga dapat berkontribusi maksimal untuk perusahaan.

Namun, hasil penelitian ini membuktikan bahwa penghargaan tidak berpengaruh signifikan terhadap produktivitas kerja. Hal ini dikarenakan hubungan yang terjadi antara penghargaan dengan produktivitas kerja yang terjadi adalah sangat rendah. Terjadinya hubungan yang sangat rendah ini mengindikasikan bahwa kebijakan terkait penghargaan yang dibangun oleh perusahaan masih belum mampu untuk memacu karayawan di dalam meningkatkan produktivitas kerjanya.

Hasil penelitian ini berbeda dengan penelitian sebelumnya oleh (Jehanzeb, 2012) yang menyatakan bahwa penghargaan berdampak pada produktivitas kerja. Namun, terdapat pula pendapat lain dari penelitian (Karami, 2013) yang mendukung hasil penelitian ini yang menyatakan bahwa penghargaan tidak berpengaruh signifikan terhadap produktivitas kerja.

\section{Pengaruh Promosi terhadap Produktivitas Kerja di Bandar Udara Internasional I Gusti Ngurah Rai - Bali


Berdasarkan parameter statistik menunjukkan bahwa thitung sebesar 0.773 lebih kecil daripada $t_{\text {tabel }}$ sebesar 1,96 pada tingkat signifikansi 5\%. Artinya bahwa Promosi tidak berpengaruh signifikan terhadap Produktivitas Kerja.

Promosi jabatan bagi karyawan akan mendorong mereka untuk meningkatkan produktivitas kerjanya agar dapat meningkatkan kesempatan untuk promosi di perusahaan. Promosi yang baik selalu mengedepankan transparansi dan objektivitas sehingga setiap karyawan memiliki kesempatan sama untuk dapat secara seimbang berlomba-lomba mendapatkan promosi jabatan.

Namun, hasil penelitian ini membuktikan bahwa promosi tidak berpengaruh signifikan terhadap produktivitas kerja. Hal ini mengindikasikan bahwa kebijakan terkait promosi yang berlaku di perusahaan masih belum mampu untuk memacu karayawan di dalam meningkatkan produktivitas kerjanya. Hasil penelitian ini berbeda dengan penelitian sebelumnya oleh (Lau, 2018) yang menyatakan bahwa promosi mempunyai efek signifikan pada produktivitas kerja. Namun, terdapat pendapat lain menurut (Noor, 2015) yang mendukung hasil penelitian ini yang menyatakan bahwa promosi tidak berpengaruh signifikan terhadap produktivitas kerja.

5. Pengaruh Kompetensi terhadap Produktivitas Kerja di Bandar Udara Internasional I Gusti Ngurah Rai - Bali

Berdasarkan parameter statistik menunjukkan bahwa $t_{\text {hitung }}$ sebesar 6.190 lebih besar daripada $t_{\text {tabel }}$ sebesar 1.96 pada tingkat signifikansi 5\%. Artinya bahwa Kompetensi berpengaruh signifikan terhadap Produktivitas Kerja.

Produktivitas kerja yang baik di perusahaan salah satunya di tentukan oleh kompetensi yang dimiliki oleh karyawannya. Karyawan yang memiliki kompetensi memadai cenderung sudah menyadari akan tugas dan tanggung jawabnya sehingga dengan sendirinya mereka akan selalu berusaha untuk menyelesaikan tugas dengan baik. Selain itu, karyawan dengan kompetensi yang baik akan selalu terpacu untuk meningkatkan kualitas dan kuantitas pekerjaan. Hal ini akan berdampak kepada peningkatan produktivitas kerja di perusahaan.

Hasil penelitian membuktikan bahwa kompetensi berpengaruh signifikan terhadap produktivitas kerja. Hal ini berarti semakin baik kompetensi karyawan, akan berdampak pada semakin meningkatnya produktivitas kerja di perusahaan. Hasil penelitian ini mendukung temuan dalam penelitian (Abbaszadeh, 2012) yang mengungkapkan bahwa terdapat pengaruh signifikan antara kompetensi terhadap produktivitas kerja.

6. Pengaruh Kepuasan Kerja terhadap Produktivitas Kerja di Bandar Udara Internasional I Gusti Ngurah Rai - Bali

Berdasarkan parameter statistik menunjukkan bahwa thitung sebesar 6.391 lebih besar daripada $t_{\text {tabel }}$ sebesar 1.96 pada tingkat signifikansi 5\%. Artinya bahwa Kepuasan Kerja berpengaruh signifikan terhadap produktivitas kerja.

Kepuasan Kerja merupakan indikator puas atau tidaknya karyawan terhadap perusahaan. Kesesuaian antara tanggung jawab dengan beban kerja dan hubungan 
antar karyawan juga mendorong karyawan untuk merasa puas dalam bekerja. Salah satu faktor yang dipengaruhi oleh kepuasan kerja yaitu produktivitas kerja. karyawan yang merasa puas dalam bekerja akan cenderung untuk melakukan yang terbaik untuk perusahaan karena perusahaan dapat memberikan rasa puas bagi karyawan. Hal ini juga akan berdampak kepada peningkatan produktivitas kerja di perusahaan.

Dalam penelitian ini, kepuasan kerja bertindak sebagai moderator di dalam hubungan penghargaan, promosi, dan juga kompetensi terhadap produktivitas kerja. Hasil penelitian membuktikan bahwa kepuasan kerja berpengaruh signifikan terhadap produktivitas kerja. Hal ini berarti semakin baik kepuasan kerja karyawan, akan berdampak pada semakin meningkatnya produktivitas kerja di perusahaan. Hasil penelitian ini serupa dengan penelitian sebelumnya oleh (Rositajati, 2017) yang menyatakan bahwa kepuasan kerja berpengaruh positif dan signifikan terhadap produktivitas kerja di perusahaan.

7. Pengaruh Penghargaan terhadap Produktivitas Kerja yang di Moderasi oleh Kepuasan Kerja di Bandar Udara Internasional I Gusti Ngurah Rai - Bali

Berdasarkan parameter statistik menunjukkan bahwa $t_{\text {hitung }}$ sebesar 2.247 lebih besar daripada $t_{\text {tabel }}$ sebesar 1.96 pada tingkat signifikansi 5\%. Artinya bahwa Penghargaan berpengaruh signifikan terhadap Produktivitas Kerja setelah dimoderasi oleh kepuasan kerja.

Berbeda dengan hasil penelitian yang menyatakan bahwa penghargaan tidak berpengaruh signifikan terhadap produktivitas kerja, penghargaan yang dimoderasi oleh kepuasan kerja justru berpengaruh signifikan terhadap produktivitas kerja. Faktor kepuasan kerja dapat menambah pengaruh penghargaan terhadap produktivitas kerja. Walaupun kebijakan dan sistem terkait penghargaan belum diterapkan dengan baik, namun karyawan masih merasa puas terhadap pekerjaannya sehingga berpengaruh di dalam meningkatkan produktivitas kerja karyawan.

Hasil penelitian membuktikan bahwa penghargaan yang dimoderasi oleh kepuasan kerja berpengaruh signifikan terhadap produktivitas kerja. Hal ini berarti semakin baik penghargaan yang dimoderasi oleh kepuasan kerja, akan berdampak pada semakin meningkatnya produktivitas kerja di perusahaan.

8. Pengaruh Promosi terhadap Produktivitas Kerja yang di Moderasi oleh Kepuasan Kerja di Bandar Udara Internasional I Gusti Ngurah Rai - Bali

Berdasarkan parameter statistik menunjukkan bahwa $t_{\text {hitung }}$ sebesar 1.212 lebih kecil daripada $t_{\text {tabel }}$ sebesar 1,96 pada tingkat signifikansi $5 \%$.

Artinya bahwa Promosi tidak berpengaruh signifikan terhadap produktivitas kerja setelah dimoderasi oleh kepuasan kerja.

Serupa dengan hasil penelitian yang menyatakan bahwa promosi tidak berpengaruh signifikan terhadap produktivitas kerja, promosi yang dimoderasi oleh kepuasan kerja juga tidak berpengaruh signifikan terhadap produktivitas kerja. Faktor kepuasan kerja belum dapat menambah pengaruh promosi terhadap produktivitas kerja. Kebijakan dan sistem terkait promosi yang belum diterapkan dengan baik, 
membuat karyawan masih merasa belum puas terhadap pekerjaannya sehingga tidak berpengaruh di dalam meningkatkan produktivitas kerja karyawan.

Hasil penelitian membuktikan bahwa promosi yang dimoderasi oleh kepuasan kerja tidak berpengaruh signifikan terhadap produktivitas kerja. Hal ini berarti moderasi kepuasan kerja pada promosi, tidak terlalu berdampak di dalam meningkatkan produktivitas kerja di perusahaan.

9. Pengaruh Kompetensi terhadap Produktivitas Kerja yang di Moderasi oleh Kepuasan Kerja di Bandar Udara Internasional I Gusti Ngurah Rai - Bali

Berdasarkan parameter statistik menunjukkan bahwa thitung sebesar 0.187 lebih kecil daripada $t_{\text {tabel }}$ sebesar 1,96 pada tingkat signifikansi 5\%. Artinya bahwa Kompetensi tidak berpengaruh signifikan terhadap produktivitas kerja setelah dimoderasi oleh kepuasan kerja.

Berbeda dengan hasil penelitian yang menyatakan bahwa kompetensi berpengaruh signifikan terhadap produktivitas kerja, kompetensi yang dimoderasi oleh kepuasan kerja justru tidak berpengaruh signifikan terhadap produktivitas kerja. Faktor moderasi kepuasan kerja mengurangi pengaruh kompetensi terhadap produktivitas kerja.

Hasil penelitian membuktikan bahwa kompetensi yang dimoderasi oleh kepuasan kerja tidak berpengaruh signifikan terhadap produktivitas kerja. Hal ini berarti moderasi kepuasan kerja pada kompetensi, tidak terlalu berdampak di dalam meningkatkan produktivitas kerja di perusahaan.

\section{Kesimpulan}

Dari hipotesis yang telah diujikan, terdapat 4 dari 9 hipotesis yang tidak memiliki pengaruh signifikan antar variabelnya. Penghargaan tidak memiliki pengaruh yang signifikan terhadap produktivitas kerja. Kebijakan pemberian penghargaan belum dapat berdampak signifikan terhadap peningkatan produktivitas kerja di perusahaan. Hal ini bukan berarti kebijakan penghargaan secara umum tidak dapat meningkatkan produktivitas, namun di dalam penelitian ini didapatkan hasil yang berbeda dari sebagian besar penelitian yang ada di tempat lain. Hal tersebut menunjukkan perlunya perbaikan terhadap kebijakan pemberian penghargian bagi karyawan untuk dapat ditinjau secara holistik baik penghargaan dari sisi finansial maupun non-finansial. Promosi tidak memiliki pengaruh yang signifikan terhadap produktivitas kerja. Kebijakan penerapan sistem promosi di perusahaan belum dapat berdampak signifikan terhadap peningkatan produktivitas kerja di perusahaan. Hal ini bukan berarti sitem promosi secara umum tidak dapat meningkatkan produktivitas, namun perlu ditinjau lebih dalam lagi terkait penerapan sistem promosi yang ada di perusahaan saat ini karena hasil penelitian ini menunjukkan hal berbeda dari penelitian lain pada umumnya dimana seharusnya promosi berpengaruh terhadap peningkatan produktivitas kerja.

Perlu dilakukan evaluasi dan perhatian lebih terhadap implementasi kebijakan pemberian penghargaan bagi karyawan. Hasil rata-rata jawaban responden untuk variabel penghargaan memiliki skor yang rendah di dalam tanggapan perilaku responden terhadap Jurnal Indonesia Sosial Teknologi, Vol. 2. No. 2 Februari 2021 
tingkat penerapan penghargaan di perusahaan. Perusahaan juga perlu senantiasa melakukan evaluasi secara berkala terhadap program penghargaan yang telah diberikan agar dampak terhadap karyawan dapat di analisis dengan tepat dan efektif.

Selain itu, Perlu dilakukan pembaruan terhadap kebijakan sistem promosi di perusahaan oleh manajemen yang menyesuaikan kebutuhan perusahaan saat ini. Hasil rata-rata jawaban responden untuk variabel promosi memiliki skor yang rendah di dalam tanggapan perilaku responden terhadap tingkat penerapan promosi di perusahaan. Perusahaan perlu melihat realita gap yang terjadi pada karyawan sehingga nantinya akan di dapat suatu formula yang efektif terkait dengan sistem promosi di perusahaan yang berdampak di dalam peningkatan produktivitas kerja.

\section{Bibliografi}

Abbaszadeh, Z. d. (2012). The Relationship Between Manager's Competencies and Employees's Producitivity in Fars Chemical Industry Company, Shiraz, Iran. World Applied Sciences Journal 19 (6): 811-817, 2012. 
Pengaruh Kompetensi Terhadap Produktivitas Kerja Dengan Kepuasan Kerja Sebagai Moderator di Bandar Udara Internasional I Gusti Ngurah Rai Bali

Earlyanti, N. I. (2019). Competency and Assessment of Performance Management Systems Affecting Position Promotion in Kendari Resort Police. The 1st International Conference of Social Science Studies and Sustainability Issues.

Haskas, Y. (2013). Pengaruh Kompetensi Terhadap Motivasi, Prestasi, Penghargaan dan Kepuasan Kerja Dosen pada Sekolah Tinggi Ilmu Kesehatan Provinsi Sulawesi Selatan. Jurnal Ilmiah Kesehatan Diagnosis. Vol. 3 Nomor 1 Tahun 2013.

Jehanzeb, K. d. (2012). Impact of Rewards and Motivation on Job Satisfaction in Banking Sector of Saudi Arabia. International Journal of Business and Social Science Vol. 3 No. 21, November 2012.

Karami, A. d. (2013). Analyzing the Effectiveness of Reward Management System on Employee Performance through the Mediating Role of Employee Motivation Case Study : Isfahan Regional Electric Company. International Journal of Academic Research in Business and Social Sciences September 2013, Vol. 3, No. 9.

Lau, H. C. (2018). Raising Employee Competency and Productivity through Best Practice in Promotion and Goal Setting. Society of Petrolium Engineers-191862-18APOG$M S$.

Noor, Z. d. (2015). Impact of Job Promotion and Job Advancement on Job Satisfaction in Universities of KPK Province of Pakistan. Sci.Int.(Lahore), 27(2), 1499-1505, 2015.

Pemerintah Republik Indonesia. https://m.hukumonline.com/pusatdata/detail/54/undangundang-nomor-3-tahun1982/document. Retrieved from Hukum Online.

PT Angkasa Pura I (Persero). (2018). Laporan Survei Kepuasan Karyawan P.T. Angkasa Pura I (Persero) Tahun 2018. Jakarta.

PT Angkasa Pura I (Persero). (2019). https://apl.co.id/id/information/annual-report. Retrieved from PT Angkasa Pura 1 (Persero).

PT Angkasa Pura I (Persero). (2019). Laporan Survei Kepuasan Karyawan P.T. Angkasa Pura 1 Tahun 2019. Jakarta.

Rositajati, H. (2017). Pengaruh Kompetensi dan Komitmen Organisasi Terhadap Promosi Jabatan Serta Implikasinya Terhadap Produktivitas (Studi Kasus pada Ditjen Renhan Kemhan). Jakarta: Universitas Pembangunan Nasional Veteran.

Sugiyono. (2016). Metode Penelitian Pendidikan (Kuantitatif, Kualitatif, dan R\&D). Bandung: CV. Alfabeta. 